\title{
The ventral premammillary nucleus links metabolic cues and reproduction
}

\section{Jose Donato Jr.* and Carol Fuzeti Elias}

Division of Hypothalamic Research, Department of Internal Medicine, University of Texas Southwestern Medical Center, Dallas, TX, USA

\section{Edited by:}

Jennifer Wootton Hill, University of

Toledo College of Medicine, USA

\section{Reviewed by:}

Sebastien G. Bouret, University of Southern California, USA

Chun-Xia Yi, University of Cincinnati, USA

\section{*Correspondence:}

Jose Donato Jr., Division of

Hypothalamic Research, Department

of Internal Medicine, University of

Texas Southwestern Medical Center,

5323 Harry Hines B/vd, Y6.206,

Dallas, TX 75390, USA

e-mail: josedonatojr@gmail.com
The amount of body fat and the energy balance are important factors that influence the timing of puberty and the normal reproductive function. Leptin is a key hormone that conveys to the central nervous system information about the individual energy reserve and modulates the hypothalamus-pituitary-gonad (HPG) axis. Recent findings suggest that the ventral premammillary nucleus (PMV) mediates the effects of leptin as a permissive factor for the onset of puberty and the coordinated secretion of luteinizing hormone during conditions of negative energy balance. In this review, we will summarize the existing literature about the potential role played by PMV neurons in the regulation of the HPG axis.

\section{Keywords: leptin, puberty, GnRH, luteinizing hormone, hypothalamus, adiposity}

\section{INTRODUCTION}

It has long been known that nutritional status is a critical factor in determining the timing of the onset of puberty (Kennedy, 1969; Frisch and McArthur, 1974). Classical studies suggested that a minimum amount of body fat is required to attain sexual maturation (Kennedy, 1969; Frisch and McArthur, 1974; Frisch, 1985). When prepubertal animals, including primates, are exposed to energy deprivation the onset of puberty is delayed or even blocked, until a favorable energy balance is achieved (Kennedy and Mitra, 1963; Kennedy, 1969; Foster and Olster, 1985). In adults, severe energy deficits are a frequent cause of hypothalamic amenorrhea (Warren et al., 1999; Welt et al., 2004; Ribeiro et al., 2007). Recent studies not only confirm the importance of the adiposity in influencing the onset of puberty, but also suggest that excess of body fat in children cause early onset of puberty (Biro et al., 2010). Epidemiological data have indicated a high prevalence of obesity among US children and adolescents (Flegal et al., 2010). Concomitantly, a higher proportion of girls have shown signs of pubertal development at earlier ages (Biro et al., 2010).

An important challenge is to understand how metabolic cues control the reproductive system. A breakthrough in the field occurred after the discovery of the gene that encodes the adipocytederived hormone leptin (Zhang et al., 1994). Soon after that, leptin became the missing piece that would complete the lipostatic theory, proposed several decades earlier (Kennedy, 1953). The lipostatic theory suggests that changes in fat deposition trigger a feedback system aiming to restore the balance between food intake and energy expenditure. Leptin levels reflect the body fat content in rodents and humans (Frederich et al., 1995a; Maffei et al., 1995; Considine et al., 1996). Overfeeding increases leptin levels, whereas food deprivation causes a strong decrease in the circulating concentration of leptin (Frederich et al., 1995b; Ahima et al., 1996; Considine et al., 1996). It has been proposed that the body interprets a high concentration of leptin as a signal of energy abundance, whereas falling levels of leptin signals starvation. Therefore, low leptin levels increase hunger and decrease energy expenditure, partly because energy-demanding physiological functions are suppressed in leptin-deficient states, presumably as a way to save energy and prolong survival (Ahima et al., 1996; Friedman and Halaas, 1998; Rosenbaum and Leibel, 1998). Reproduction is one of the physiological functions strongly affected by leptin (Barash et al., 1996; Ahima et al., 2000). Because lack of leptin is interpreted as a signal of starvation, leptin-deficient individuals become hyperphagic, massively obese and infertile, and exhibit a series of metabolic dysfunctions (Zhang et al., 1994; Campfield et al., 1995; Halaas et al., 1995; Pelleymounter et al., 1995; Montague et al., 1997; Strobel et al., 1998). Leptin treatment rescues the alterations in body weight, metabolism, and the reproductive system (Ahima et al., 1996; Barash et al., 1996; Chehab et al., 1996; Mounzih et al., 1997; Farooqi et al., 1999). In addition, exogenous leptin administration causes early onset of puberty in mice (Ahima et al., 1997; Chehab et al., 1997), and a similar mechanism could account for the trend observed in overweight children (Biro et al., 2010).

After the discovery of leptin, many studies focused on deciphering the mechanism by which leptin regulates the reproductive system. Although leptin receptors (LepR) are expressed in many organs, including pituitary gland and gonads (Zamorano et al., 1997), it is now clear that the main target of leptin is the brain (Cohen et al., 2001; de Luca et al., 2005). The expression of LepR is found in innumerous brain nuclei, particularly in specific populations of hypothalamic neurons (Schwartz et al., 1996; Elmquist et al., 1998; Scott et al., 2009). However, defining the key neuronal population that mediates the effects of leptin on reproduction has proven to be a challenging task (Hill et al., 2008; Castellano et al., 2010; Donato et al., 2011a; Louis et al., 2011). Recent findings suggest that the ventral premammillary nucleus (PMV) 
is the long sought area in which leptin modulates the activity of the reproductive system (Donato et al., 2009, 2011b; Leshan et al., 2009; Louis et al., 2011). In this review, we will summarize the existing literature about the potential role played by PMV neurons in the regulation of the hypothalamus-pituitary-gonad (HPG) axis.

\section{THE NEUROCHEMICAL PROFILE OF PMV NEURONS HIGHLIGHTS A KEY INTEGRATIVE FUNCTION}

Ventral premammillary nucleus neurons exhibit a broad expression of receptors for hormones related to the regulation of the energy balance (Table 1). PMV neurons express LepR (Elmquist et al., 1998; Scott et al., 2009), the ghrelin receptor, in mice but not in rats (Zigman et al., 2006) and the insulin receptor (Figure 1A). Innumerous receptors for neurotransmitters involved with the regulation of energy balance are also found in the PMV, including the cannabinoid receptor 1 (Figure 1B), the melanocortin-4 receptor in mice (Liu et al., 2003) but not in rats (Kishi et al., 2003), the orexin receptor 1 and 2 (Marcus et al., 2001), the neuropeptide Y Y1 receptor (higher expression in mice than rats; Kishi et al., 2005), and the vasopressin receptor in hamsters (sexually dimorphic and dependent upon photoperiod length; Dubois-Dauphin et al., 1991).

Ventral premammillary nucleus neurons are potential targets of sex hormones (Table 1), as they express a dense amount of androgen receptor (AR) and a moderate to low amount of estrogen receptor $\alpha$ and $\beta(\mathrm{ER} \alpha$ and $\mathrm{ER} \beta)$ and progesterone receptor (Simerly et al., 1990; Yokosuka and Hayashi, 1996; Merchenthaler et al., 2004; Intlekofer and Petersen, 2011). The relatively high ratio of AR to ER and the lack of definitive data demonstrating the expression of aromatase in the PMV indicate a potential role for androgens in PMV neuronal biology (Yokosuka and Hayashi, 1996; Wu et al., 2009). Despite the strong presence of sexual steroid receptors in the PMV, it has not been determined whether changing levels of sexual hormones affect the neuronal activity or gene expression in this area.

In addition to sex steroid receptors, several neurotransmitters are expressed by PMV neurons (Table 1), including glutamate (Ziegler et al., 2002). The expression of glutamatergic markers, such as vesicular glutamate transporter 2 (vGluT2), can be found in the entire extension of the PMV and show a $94 \%$ colocalization with neurons that express LepR (Donato et al., 2011b). On the other hand, there is virtually no expression of GABAergic markers in the PMV, such as glutamic acid decarboxylase 67 (GAD67) or vesicular GABA transporter (vGaT; Donato et al., 2010a; Vong et al., 2011). Thus, the projections originated from PMV neurons are thought to be excitatory due to their glutamatergic component.

Peptidergic neurotransmitters are also expressed by PMV neurons (Table 1), including cocaine and amphetamine regulated transcript (CART), substance $\mathrm{P}$ (a tachykinin family member) and

Table 1 | Neurochemical characteristics of the ventral premammillary nucleus (PMV).

\begin{tabular}{|c|c|c|c|}
\hline & Expression level & Studied species & Sexual dimorphism or specie-related differences in the expression level \\
\hline \multicolumn{4}{|c|}{ NEUROTRANSMITTERS/HORMONES } \\
\hline Glutamate & +++ & $M, R$ & \\
\hline Nitric oxide & +++ & $M, R, S$ & \\
\hline CART & ++ & $M, R, S$ & Higher expression in rats and in sheep, compared to mice \\
\hline Substance $P$ & ++ & $\mathrm{R}$ & Sexually dimorphic (higher in male) \\
\hline Enkephalin & ++ & $\mathrm{R}, \mathrm{Hu}$ & \\
\hline Dopamine & - & $M, R, B$ & Described only in birds. Absent in rodents \\
\hline Melatonin & - & B & Described only in birds \\
\hline \multicolumn{4}{|l|}{ RECEPTORS } \\
\hline Leptin receptor & +++ & $M, R$ & \\
\hline Insulin receptor & ++ & M & \\
\hline Ghrelin receptor & ++ & $M, R$ & In mice but not in rats \\
\hline Androgen receptor & +++ & $M, R$ & \\
\hline Estrogen receptor $\alpha$ & ++ & $M, R$ & \\
\hline Estrogen receptor $\beta$ & + & M & \\
\hline Progesterone receptor & + & $\mathrm{R}$ & \\
\hline Cannabinoid receptor 1 & +++ & $\mathrm{M}$ & \\
\hline Melanocortin receptor 4 & ++ & $M, R$ & In mice but not in rats \\
\hline Neuropeptide YY1 receptor & +++ & $M, R$ & Higher expression in mice than rats \\
\hline Orexin receptor 1 & ++ & $\mathrm{R}$ & \\
\hline Orexin receptor 2 & +++ & $\mathrm{R}$ & \\
\hline Vasopressin receptor (binding) & +++ & $\mathrm{Ha}$ & Sexually dimorphic and dependent upon photoperiod length \\
\hline Melatonin receptor (binding) & +++ & S & Described only in sheep \\
\hline Melanopsin (photopigment) & - & $\mathrm{B}$ & Described only in birds \\
\hline
\end{tabular}

Expression level: +++, high; ++, moderate; +, low; -, not described.

Species: $B$, birds; Ha, hamsters, Hu, humans; $M$, mouse; $R$, rat; $S$, sheep. 


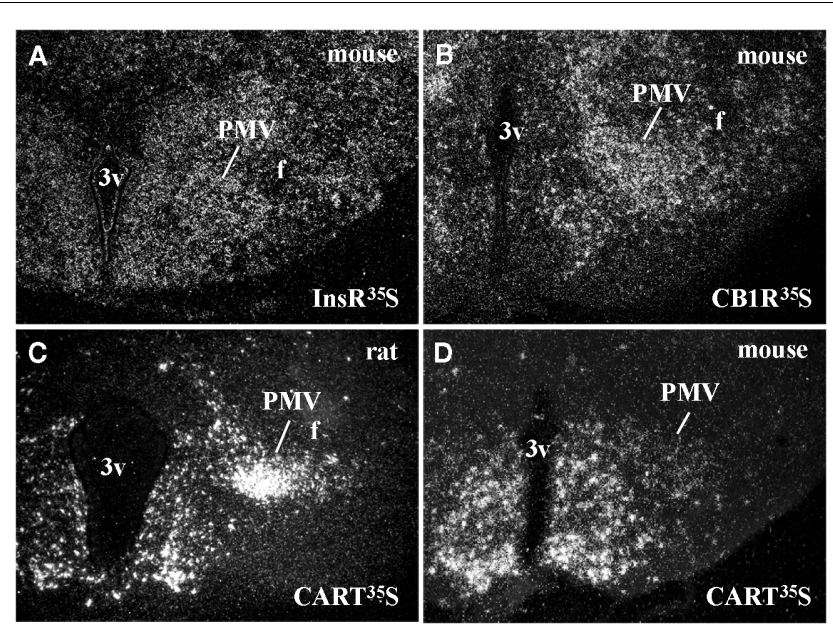

FIGURE 1 | Neurochemical characteristics of the ventral premammillary nucleus (PMV). (A,B) Darkfield photomicrographs demonstrating the distribution of insulin receptor (InsR) mRNA (A) and cannabinoid receptor type 1 (CB1R) mRNA (B) in the mouse PMV. (C,D) Darkfield photomicrographs demonstrating the distribution of cocaine and amphetamine regulated transcript (CART) mRNA in the rat (C) and in the mouse (D) PMV. Note the abundance of CART mRNA in the PMV of rats compared to mice.

enkephalin (Wamsley et al., 1980; Shimada et al., 1987; Larsen, 1992; Douglass et al., 1995; Sukhov et al., 1995). However, sexually dimorphic or species-related differences exist. While the PMV of rats densely expresses CART mRNA and peptide (Douglass et al., 1995; Koylu et al., 1997), the PMV of mice exhibits low CART expression (Figures 1C-D). In addition, the number of neurons that express tachykinin peptides in the PMV is higher in male than in female rats (Akesson, 1993). PMV neurons also densely express neuronal nitric oxide synthase (nNOS), which catalyzes the synthesis of nitric oxide (NO; Vincent and Kimura, 1992).

\section{PMV NEURONS ARE NEUROCHEMICALLY AND NEUROANATOMICALLY WELL POSITIONED TO REGULATE REPRODUCTION}

Many of the neurotransmitters expressed in the PMV are involved in the neuroendocrine regulation of reproduction. For example, glutamatergic inputs were shown to induce gonadotropinreleasing hormone $(\mathrm{GnRH})$ release and subsequent activation of HPG axis (Brann and Mahesh, 1994; Gargiulo and Donoso, 1995; Dhandapani and Brann, 2000; Mahesh and Brann, 2005). Moreover, glutamate facilitates the expression of sexual behaviors (Gargiulo and Donoso, 1995) and has regulatory effects on the timing of puberty (Zamorano et al., 1998; Terasawa and Fernandez, 2001; Ojeda et al., 2006). Of note, intracerebroventricular administration of glutamate receptor agonists, such as NMDA, elicits secretion of $\mathrm{GnRH}$ and luteinizing hormone (LH), even in Kiss1 and Kiss1r knockout mice, suggesting a role for glutamatergic neurotransmission outside the Kiss 1 neuronal system (d'Anglemont de Tassigny et al., 2010). CART peptide was shown to mediate the stimulatory effects of leptin on $\mathrm{GnRH}$ secretion in vitro and in vivo (Lebrethon et al., 2000, 2007; Parent et al.,
2000). In addition, NO has been implicated in the regulation of sexual behaviors and HPG axis (Moretto et al., 1993; Rettori et al., 1993; Mani et al., 1994; Benelli et al., 1995; Nelson et al., 1995). A complete disruption of Nos1 gene results in hypogonadism and infertility (Gyurko et al., 2002). Furthermore, several studies found that $\mathrm{NO}$ is a key neurotransmitter that mediates leptin-induced GnRH/LH secretion (Yu et al., 1997; McCann et al., 1999; Watanobe and Schioth, 2001; Reynoso et al., 2007). Recently, we reported that $73 \%$ of leptin responsive cells in the PMV express NO-synthesizing enzymes (Donato et al., 2010b). Leptin does not affect the expression of Nos1 mRNA in the PMV, but low leptin levels, as in fasting or in $o b / o b$ mice, cause a reduction in the number of PMV neurons expressing the phosphorylated form of $\mathrm{nNOS}^{\mathrm{S} 1412}$ (pnNOS). The phosphorylation of nNOS at Ser1412 increases nNOS enzymatic activity (Parkash et al., 2010) and acute injection of leptin restores the number of pnNOS neurons in the PMV of fasted mice (Donato et al., 2010b).

The projections of PMV neurons were first described in rats using the neurotracer Phaseolus vulgaris leucoagglutinin (Canteras et al., 1992b). It was demonstrated that PMV neurons project mainly to the periventricular zone of the hypothalamus, which is composed of nuclei involved in the regulation of anterior pituitary function. PMV neurons also project to major nuclei of the sexually dimorphic circuitry, including the ventrolateral part of the ventromedial nucleus of hypothalamus (VMH), medial preoptic nucleus, bed nuclei of the stria terminalis (BST), ventral lateral septal nucleus, posterodorsal part of the medial nucleus of the amygdala (MeA), and posterior nucleus of the amygdala (Canteras et al., 1992b). It is interesting that the major neuronal inputs to the PMV originate from neurons located in the sexually dimorphic circuitry, highlighting the intense intercommunication between this circuitry and the PMV (Simerly and Swanson, 1988; Canteras et al., 1992a,b, 1994, 1995; Coolen and Wood, 1998). For example, PMV is densely innervated by neurons located in the MeA, including cells that express urocortin 3 (Canteras et al., 1995; Coolen and Wood, 1998; Cavalcante et al., 2006b).

More recent studies in mice and in rats using genetic tools in combination with tracing techniques highlighted a putative role of the PMV in the regulation of the HPG axis. It was shown that PMV neurons project directly to GnRH perikarya in the medial preoptic area (MPA; Rondini et al., 2004; Boehm et al., 2005; Leshan et al., 2009) and to GnRH fibers in the median eminence (Donato et al., 2011b). Interestingly, among all neurons that express LepR, only those in the PMV and a subpopulation of neurons in the MPA seem to project directly to GnRH neurons (Louis et al., 2011). In addition, PMV neurons project to the anteroventral periventricular nucleus (AVPV; Canteras et al., 1992b; Rondini et al., 2004; Hahn and Coen, 2006), a key site for female reproductive function (Wiegand and Terasawa, 1982; Gottsch et al., 2004; Herbison, 2008). The AVPV contains a subpopulation of kisspeptin neurons, which is critical for the preovulatory LH surge (Smith et al., 2006; Herbison, 2008; Cravo et al., 2011). We have recently found that fibers from PMV neurons make apparent synaptic contact with kisspeptin neurons in the AVPV (Donato et al., 2011b). The arcuate nucleus $(\mathrm{ARH})$ also receives a dense projection from PMV neurons (Canteras et al., 1992b), but whether kisspeptin neurons in the ARH or a specific population of ARH neurons is selectively targeted 
by PMV inputs is still unknown. Overall, PMV neurons potentially regulate the reproductive system directly through inputs to GnRH neurons and also to upstream neuronal populations, such as kisspeptin cells.

\section{PMV NEURONS ARE RESPONSIVE TO CONSPECIFIC BEHAVIORS AND SOCIALLY RELEVANT CUES}

Previous studies using electrolytic lesions described a potential role for PMV neurons in odor-induced LH secretion in rats (Beltramino and Taleisnik, 1985). Olfaction is a critical sense used by rodents to discriminate socially relevant cues and to trigger social behaviors, including sexual behaviors (Romero et al., 1990; Halpern and Martinez-Marcos, 2003; Yoon et al., 2005; Brennan and Zufall, 2006). In response to conspecific odors, males and females of different species exhibit increased circulating levels of gonadotropins and sex steroids (Maruniak and Bronson, 1976; Kamel et al., 1977; Beltramino and Taleisnik, 1983; Coquelin et al., 1984). Rats and mice exposed to conspecific odors show a large number of neurons expressing Fos immunoreactivity (Fos-ir) in the PMV, which suggests that the PMV is involved in the neuronal circuitry that conveys olfactory information (Yokosuka et al., 1999; Cavalcante et al., 2006a; Leshan et al., 2009; Donato et al., 2010a). Moreover, roughly 50\% of PMV neurons activated by opposite-sex odor express CART and, in male rats, CART mRNA increases after exposure to female odors (Cavalcante et al., 2006a). Most of the CART neurons in the PMV express the enzymes that synthesize NO. Besides, a parcel of nitrergic neurons is stimulated by female odors and virtually all nitrergic cells in the PMV express ARs (Yokosuka and Hayashi, 1996). Altogether, these studies indicate that PMV is apt to integrate information about circulating levels of sexual hormones and socially relevant cues (through brain areas related to pheromonal processing, such as MeA or BST) and generate appropriate neuroendocrine responses to modulate socially relevant behaviors.

The PMV may also be involved in the expression of conspecific behaviors because PMV neurons of male rats are also responsive to conspecific male odors (Donato et al., 2010a). In addition, PMV neurons express Fos-ir after mating or agonistic behavior (KollackWalker and Newman, 1995; Coolen et al., 1996; Pfaus and Heeb, 1997). Previous studies showed that lesions of the premammillary area increases aggression between males of the same species (Van Den Berg et al., 1983). However, these studies should be interpreted with caution due to the extension of the lesion. Restricted and/or selective lesions are required to determine the real contribution of the PMV in aggressive behaviors.

An interesting question is whether nutritional conditions may alter the responsiveness of an individual to environmental cues. PMV neurons are the target of metabolic cues and also respond to socially relevant sensory stimulation. Of note, $44 \%$ of the LepRexpressing cells in the PMV of male mice are activated by female odors, whereas in female mice, $18 \%$ of LepR cells are activated by male odors (Leshan et al., 2009). These findings suggest that food availability or energy stored affect neuronal responses to odors. However, we observed that fasting caused no changes in female odor-induced Fos-ir in the PMV and in the MeA of male rats compared to normally fed controls (Donato et al., 2010a). Although this finding may suggest a dissociation of neuronal responses to different stimuli, it is important to mention that induction of Fos protein may not be the definitive indicator of changes in neuronal activity or responsiveness. Further studies will be necessary to determine the influence of the nutritional state on the response to environmental stimulation.

\section{PREMAMMILLARY HYPOTHALAMIC AREA MEDIATES SEASONAL REPRODUCTION IN EWES AND BIRDS}

Although most of the studies about the PMV have used rats and mice as experimental models, there are several pieces of evidence that the premammillary hypothalamic area $(\mathrm{PMH})$ also plays a key role in reproductive function of seasonal breeders (i.e., sheep and birds). Seasonal reproduction is a strategy used by several species to increase survival of offspring by reproducing during a period of the year when the environment offers favorable conditions. In sheep, the major environmental cue controlling reproduction is the photoperiod or day length (Duan et al., 2007). Changes in day light exposure alter the synthesis and secretion of the pineal gland hormone melatonin, which in turn binds to hypothalamic nuclei and modulates the pulsatile secretion of GnRH (Emilsson et al., 1999; Hazlerigg and Wagner, 2006; Goodman et al., 2010). The $\mathrm{PMH}$ of ewes is composed of the caudal ARH, the PMV and the ventral tuberomammillary nucleus. Similarly to rats, PMV neurons in ewes express CART and nNOS (Sliwowska et al., 2004). In addition, $\mathrm{PMH}$ of ewes is a melatonin binding site. Bilateral microimplantation of melatonin into the PMV of ewes stimulates LH secretion (Malpaux et al., 1998), indicating that in sheep, the PMV appears to play a key role in seasonal reproduction.

The reproductive cycle of a variety of avian species is regulated by circadian mechanisms driven by intrinsic oscillators (Petersen et al., 1996; Wikelski et al., 2008; Goodman et al., 2010). These mechanisms are modulated by light-sensitive neuronal populations located in the caudal hypothalamus, in a site identified as the PMH (Kang et al., 2007). In birds, a subpopulation of $\mathrm{PMH}$ neurons expresses dopamine, a neurotransmitter known to affect the secretion of several reproductive hormones, including $\mathrm{LH}, \mathrm{FSH}$, and prolactin. Using a complex paradigm of lightinduced GnRH neuronal activation, studies identified in turkeys a photosensitive subpopulation of dopaminergic $\mathrm{PMH}$ neurons likely involved in GnRH secretion (Thayananuphat et al., 2007). Dopaminergic neurons (immunoreactive to tyrosine hydroxylase) in the PMH of turkeys coexpress melatonin and its synthesizing enzymes (Kang et al., 2007). Dopamine-melatonin neurons in the PMH exhibit high activity at the photosensitive phase, which was associated with higher dopaminergic neurotransmission and GnRH activation. Additionally, these neurons express the photoreceptive molecule melanopsin, which is involved in extra-retinal photoreception in birds and non-mammalian vertebrates. In hens, the expression of melanopsin mRNA in the $\mathrm{PMH}$ is downregulated by light in a series of models and shows a diurnal regulation; it is high during the night and low during the day (Kang et al., 2010). The PMH of turkeys also presents a distinct circadian expression of clock genes compared to the pineal gland and the brain master clock, the suprachiasmatic nucleus. In particular, Cry 1 and Per 3 seem to mediate the photic responses associated with the control of the reproductive system (Leclerc et al., 2010). 


\section{PMV NEURONS INTEGRATE METABOLIC CUES TO REGULATE} REPRODUCTION RATHER THAN ENERGY BALANCE

The high expression of receptors of hormones related with the regulation of the energy balance might imply that the PMV is involved in the control of energy balance. However, bilateral excitotoxic lesions of the PMV did not affect body weight, mean food intake and circulating leptin levels in adult female rats (Donato et al., 2009). Nonetheless, PMV-lesioned rats exhibit an attenuated reduction in food intake between the proestrus and the estrus day (Donato et al., 2009). Female rats normally show a decreased food intake in the behavioral estrus that is linked with the high estrogen levels observed during the proestrus day (Drewett, 1973; Geary et al., 2001; Asarian and Geary, 2006). Therefore, the regulation of food intake across the estrous cycle by PMV neurons can be an indirect consequence of changes in sexual hormone levels after lesions of the PMV.

Leptin exerts a pivotal role in the long-term regulation of energy balance (Schwartz, 2006; Gautron and Elmquist, 2011). As mentioned, leptin administration to leptin-deficient mice (ob/ob) rescues all the metabolic and neuroendocrine deficits observed in these mice (Campfield et al., 1995; Halaas et al., 1995; Pelleymounter et al., 1995; Chehab et al., 1996). Following the same paradigm, we generated $o b / o b$ mice with bilateral lesions of the PMV (Donato et al., 2011b). Upon leptin treatment, these mice showed drastic reduction in food intake and body weight, indicating that leptin may restore the metabolic deficits of $o b / o b$ female mice in the absence of PMV neurons (Donato et al., 2011b). To further investigate the role played by LepR in the PMV, we generated a LepR-null mouse model in which LepR is expressed selectively in PMV neurons. We found that endogenous expression of LepR only in the PMV did not affect food intake, body weight, and fat mass in male and female mice (Donato et al., 2011b). In agreement with this, a recent study found that after genetic ablation of LepR expression from all glutamatergic (vGluT2-positive) neurons, which includes PMV cells, only minor changes in body weight, food intake, and fat mass were observed in male and female mice (Vong et al., 2011). Overall, these results suggest that despite the presence of innumerous receptors involved with the regulation of energy balance, PMV neurons are not key players in the modulation of food intake and body weight. Rather, PMV neurons may function as a key integrative site conveying metabolic cues to the reproductive system. Accordingly, PMV lesions cause a temporary anestrus in rats (persistent leukocytes in the vaginal smears). However, after a few weeks PMV-lesioned rats recover their cyclicity, although vaginal cytology continues to exhibit an atypical mixed cell profile (Donato et al., 2009). Several weeks after lesions of the PMV, rats still show reduced concentration of LH and estradiol and decreased activation of AVPV and GnRH neurons at the time of the preovulatory LH surge but no changes in Kiss1 mRNA expression (Donato et al., 2009). Possibly secondary to decreased gonadotropin levels, the ovaries of PMV-lesioned rats display a lower number of antral follicles and a trend toward a reduction in the number of corpora lutea (Donato et al., 2009). These results indicate that the PMV is required for the normal activity of the HPG axis in female rats.
Following the same line, we hypothesized that the PMV would be apt to mediate the effects of leptin on the reproductive neuroendocrine axis. To test this model, we used a well-established paradigm in which leptin treatment can restore or increase LH levels in fasted rodents (Ahima et al., 1996; Nagatani et al., 1998; Gonzalez et al., 1999; Watanobe et al., 1999; Chan et al., 2003). Lesions of the PMV blocked the stimulatory effect of leptin on LH secretion in fasted rats (Donato et al., 2009). In order to investigate putative signaling pathways that mediate the acute effects of leptin on PMV neurons, patch-clamp recordings of hypothalamic slices were performed. Leptin caused a rapid depolarization of $\sim 75 \%$ of LepR-expressing neurons in the PMV through a putative TRPC channel (Leshan et al., 2009; Williams et al., 2011). The other $25 \%$ recorded LepR cells were hyperpolarized in response to leptin, and this response required the activation of a putative Katp channel. Importantly, pharmacological or genetic disruption of the phosphoinositide 3-kinase (PI3K) pathway prevented the leptininduced changes in the activity of PMV LepR neurons (Williams et al., 2011). These results indicate that PI3K is required for the acute changes in biophysical properties of PMV neurons induced by leptin. Whether these changes in cellular activity underlie the physiological effects of leptin are under investigation.

We further assessed whether leptin signaling in PMV neurons is critical to induce the onset of puberty and restore fertility in leptin- or LepR-deficient mouse models. Lesions of the PMV in female $o b / o b$ mice reduced the capacity of exogenous leptin to induce sexual maturation. Besides, acute injection of leptin did not increase LH and progesterone levels in PMV-lesioned $o b / o b$ mice, as observed in PMV-intact ob/ob mice (Donato et al., 2011b). In addition, female LepR-null mice with endogenous re-expression of LepR in PMV neurons showed unambiguous signs of sexual maturation, such as vaginal opening, increased uterus weight and size, and ovaries with corpora lutea. After a period of 6 weeks of breeding tests, $50 \%$ of mice with selective reactivation of LepR in PMV neurons became pregnant, despite their obese and diabetic phenotype (Donato et al., 2011b). Notably, the improvement of the infertile phenotype of the LepR-null mice following PMV LepR reactivation was only observed in females, not in males. Additional studies will be necessary to tackle this sex-related difference. As previously mentioned, neurotransmitters found in the PMV, such as glutamate and NO, were shown to stimulate the release of GnRH. Moreover, earlier studies suggested that the lack of leptin signaling causes a deficient release of $\mathrm{GnRH}$ because $o b / o b$ and $d b / d b$ mice have high content of GnRH in the median eminence/medial basal hypothalamus (ME/MBH; Johnson and Sidman, 1979; Batt et al., 1982). Re-expression of LepR only in the PMV normalized the ME/MBH GnRH content in female LepRnull mice. Together, these findings have determined the PMV as a key site linking leptin action and the female reproductive physiology.

\section{CONCLUDING REMARKS}

Overall, this review highlights a series of recent data demonstrating that PMV neurons are apt to mediate the effects of leptin on GnRH secretion. The stimulatory effect of PMV neurons on GnRH release is possibly mediated by the coordinated effects of 


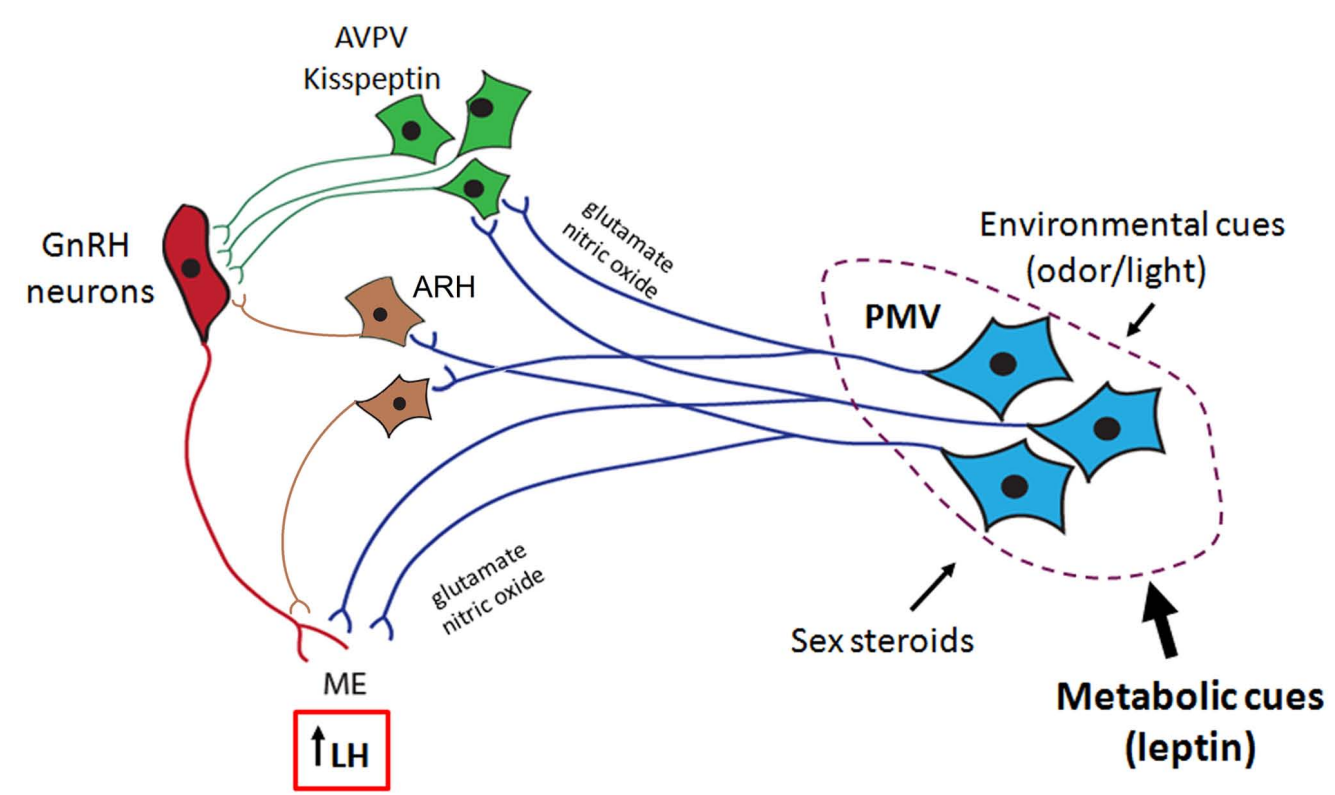

FIGURE 2 | Proposed role for the ventral premammillary nucleus (PMV) in the female reproductive physiology. The PMV integrates environmental cues (odors in rodents and daylight in seasonal breeders) and signals from the internal milieu related to the reproductive status (sex steroids) and energy store (leptin and insulin). PMV neurons express excitatory neurotransmitters (e.g., glutamate and nitric oxide) and directly project to the anteroventral periventricular nucleus (AVPV), to the arcuate nucleus (ARH), and to gonadotropin-releasing hormone $(\mathrm{GnRH})$ neurons. Once stimulated, PMV neurons activate the target sites inducing $\mathrm{GnRH}$ release and $\mathrm{LH}$ secretion from the pituitary gland. glutamate and $\mathrm{NO}$ on GnRH terminals in the median eminence (Figure 2). Although it is very likely that other neuronal populations also convey metabolic cues to modulate the HPG axis, the existing evidence suggests that the PMV is a key site relaying the effects of leptin on the reproductive neuroendocrine axis. We postulate that through PMV neurons, leptin modulates the influence of adiposity on the timing of puberty and the coordinated secretion of LH during conditions of negative energy balance. The data presented in this review provide the physiological and neuroanatomical basis underlying the effects of leptin on the HPG axis.

\section{REFERENCES}

Ahima, R. S., Dushay, J., Flier, S. N., Prabakaran, D., and Flier, J. S. (1997). Leptin accelerates the onset of puberty in normal female mice. $J$. Clin. Invest. 99, 391-395.

Ahima, R. S., Prabakaran, D., Mantzoros, C., Qu, D., Lowell, B., Maratos-Flier, E., and Flier, J. S. (1996). Role of leptin in the neuroendocrine response to fasting. Nature 382, 250-252.

Ahima, R. S., Saper, C. B., Flier, J. S., and Elmquist, J. K. (2000). Leptin regulation of neuroendocrine systems. Front. Neuroendocrinol. 21, 263-307.

Akesson, T. R. (1993). Androgen concentration by a sexually dimorphic population of tachykininimmunoreactive neurons in the rat ventral premammillary nucleus. Brain Res. 608, 319-323.

Asarian, L., and Geary, N. (2006). Modulation of appetite by gonadal steroid hormones. Philos. Trans. R. Soc. Lond. B Biol. Sci. 361, 1251-1263.

Barash, I. A., Cheung, C. C., Weigle, D. S., Ren, H., Kabigting, E. B., Kuijper, J. L., Clifton, D. K., and Steiner, R. A. (1996). Leptin is a metabolic signal to the reproductive system. Endocrinology 137, 3144-3147.

Batt, R. A., Everard, D. M., Gillies, G., Wilkinson, M., Wilson, C. A., and Yeo, T. A. (1982). Investigation into the hypogonadism of the obese mouse (genotype ob/ob). J. Reprod. Fertil. 64, 363-371.

Beltramino, C., and Taleisnik, S. (1983). Release of $\mathrm{LH}$ in the female rat

\section{ACKNOWLEDGMENTS}

We would like to thank members of our laboratory (Roberta Cravo and Renata Frazão) at the Department of Internal Medicine, Division of Hypothalamic Research, University of Texas Southwestern Medical Center, Dallas - TX (USA) for the active participation in the data discussed in this review. We are also indebted with Dr. Joel K. Elmquist, Dr. Jeffrey Zigman, Dr. Streamson Chua, and Dr. Jean Zhao for the mouse models used in our studies. The research in our laboratory has been funded by grants from NIH (R01HD061539), Foundation for Prader-Willi Research, the Regents Scholar Award and Young Investigator Research Award from UTSW.

by olfactory stimuli. Effect of the removal of the vomeronasal organs or lesioning of the accessory olfactory bulbs. Neuroendocrinology 36, 53-58.

Beltramino, C., and Taleisnik, S. (1985). Ventral premammillary nuclei mediate pheromonal-induced $\mathrm{LH}$ release stimuli in the rat. Neuroendocrinology 41, 119-124.

Benelli, A., Bertolini, A., Poggioli, R., Cavazzuti, E., Calza, L., Giardino, L., and Arletti, R. (1995). Nitric oxide is involved in male sexual behavior of rats. Eur. J. Pharmacol. 294, 505-510.

Biro, F. M., Galvez, M. P., Greenspan, L. C., Succop, P. A., Vangeepuram, N., Pinney, S. M., Teitelbaum, S., Windham, G. C., Kushi, L. H., and Wolff, M. S. (2010). Pubertal assessment method and baseline characteristics in a mixed longitudinal study of girls. Pediatrics 126, e583-e590.

Boehm, U., Zou, Z., and Buck, L. B. (2005). Feedback loops link odor and pheromone signaling with reproduction. Cell 123, 683-695.

Brann, D. W., and Mahesh, V. B. (1994). Excitatory amino acids: function and significance in reproduction and neuroendocrine regulation. Front. Neuroendocrinol. 15, 3-49.

Brennan, P. A., and Zufall, F. (2006). Pheromonal communication in vertebrates. Nature 444, 308-315.

Campfield, L. A., Smith, F. J., Guisez, Y., Devos, R., and Burn, P. (1995). Recombinant mouse $\mathrm{OB}$ protein: evidence for a peripheral signal linking adiposity and central neural networks. Science 269, 546-549. 
Canteras, N. S., Simerly, R. B., and Swanson, L. W. (1992a). Connections of the posterior nucleus of the amygdala. J. Comp. Neurol. 324, 143-179.

Canteras, N. S., Simerly, R. B., and Swanson, L. W. (1992b). Projections of the ventral premammillary nucleus. J. Comp. Neurol. 324, 195-212.

Canteras, N. S., Simerly, R. B., and Swanson, L. W. (1994). Organization of projections from the ventromedial nucleus of the hypothalamus: a Phaseolus vulgaris-leucoagglutinin study in the rat. J. Comp. Neurol. 348, 41-79.

Canteras, N. S., Simerly, R. B., and Swanson, L. W. (1995). Organization of projections from the medial nucleus of the amygdala: a PHAL study in the rat. J. Comp. Neurol. 360, 213-245.

Castellano, J. M., Bentsen, A. H., Mikkelsen, J. D., and Tena-Sempere, M. (2010). Kisspeptins: bridging energy homeostasis and reproduction. Brain Res. 1364, 129-138.

Cavalcante, J. C., Bittencourt, J. C., and Elias, C. F. (2006a). Female odors stimulate CART neurons in the ventral premammillary nucleus of male rats. Physiol. Behav. 88, 160-166.

Cavalcante, J. C., Sita, L. V., Mascaro, M. B., Bittencourt, J. C., and Elias, C. F. (2006b). Distribution of urocortin 3 neurons innervating the ventral premammillary nucleus in the rat brain. Brain Res. 1089, 116-125.

Chan, J. L., Heist, K., Depaoli, A. M., Veldhuis, J. D., and Mantzoros, C. S. (2003). The role of falling leptin levels in the neuroendocrine and metabolic adaptation to short-term starvation in healthy men. J. Clin. Invest. 111, 1409-1421.

Chehab, F. F., Lim, M. E., and Lu, R. (1996). Correction of the sterility defect in homozygous obese female mice by treatment with the human recombinant leptin. Nat. Genet. 12, 318-320.

Chehab, F. F., Mounzih, K., Lu, R., and Lim, M. E. (1997). Early onset of reproductive function in normal female mice treated with leptin. Science 275, 88-90.

Cohen, P., Zhao, C., Cai, X., Montez, J. M., Rohani, S. C., Feinstein, P., Mombaerts, P., and Friedman, J. M. (2001). Selective deletion of leptin receptor in neurons leads to obesity. J. Clin. Invest. 108, 1113-1121.

Considine, R. V., Sinha, M. K., Heiman, M. L., Kriauciunas, A., Stephens, T. W., Nyce, M. R., Ohannesian, J. P., Marco, C. C., Mckee, L. J., Bauer, T. L., and Caro, J. F. (1996). Serum immunoreactive-leptin concentrations in normal-weight and obese humans. N. Engl. J. Med. 334, 292-295.

Coolen, L. M., Peters, H. J., and Veening, J. G. (1996). Fos immunoreactivity in the rat brain following consummatory elements of sexual behavior: a sex comparison. Brain Res. 738, 67-82.

Coolen, L. M., and Wood, R. I. (1998). Bidirectional connections of the medial amygdaloid nucleus in the Syrian hamster brain: simultaneous anterograde and retrograde tract tracing. J. Comp. Neurol. 399, 189-209.

Coquelin, A., Clancy, A., Macrides, F., Noble, E., and Gorski, R. (1984). Pheromonally induced release of luteinizing hormone in male mice: involvement of the vomeronasal system. J. Neurosci. 4, 2230-2236.

Cravo, R. M., Margatho, L. O., OsborneLawrence, S., Donato, J. Jr., Atkin, S., Bookout, A. L., Rovinsky, S., Frazão, R., Lee, C. E., Gautron, L., Zigman, J. M., and Elias, C. F. (2011). Characterization of Kiss1 neurons using transgenic mouse models. Neuroscience 173, 37-56.

d'Anglemont de Tassigny, X., Ackroyd, K. J., Chatzidaki, E. E., and Colledge, W. H. (2010). Kisspeptin signaling is required for peripheral but not central stimulation of gonadotropin-releasing hormone neurons by NMDA. J. Neurosci. 30, 8581-8590.

de Luca, C., Kowalski, T. J., Zhang, Y., Elmquist, J. K., Lee, C., Kilimann, M. W., Ludwig, T., Liu, S. M., and Chua, S. C. Jr. (2005). Complete rescue of obesity, diabetes, and infertility in $\mathrm{db} / \mathrm{db}$ mice by neuron-specific LEPR-B transgenes. J. Clin. Invest. 115, 3484-3493.

Dhandapani, K. M., and Brann, D. W. (2000). The role of glutamate and nitric oxide in the reproductive neuroendocrine system. Biochem. Cell Biol. 78, 165-179.

Donato, J. Jr., Cavalcante, J. C., Silva, R. J., Teixeira, A. S., Bittencourt, J. C., and Elias, C. F. (2010a). Male and female odors induce Fos expression in chemically defined neuronal population. Physiol. Behav. 99, 67-77.

Donato, J. Jr., Frazao, R., Fukuda, M., Vianna, C. R., and Elias, C. F. (2010b). Leptin induces phosphorylation of neuronal nitric oxide synthase in defined hypothalamic neurons. Endocrinology 151, 5415-5427.

Donato, J. Jr., Silva, R. J., Sita, L. V., Lee, S., Lee, C., Lacchini, S., Bittencourt, J. C., Franci, C. R., Canteras, N. S., and Elias, C. F. (2009). The ventral premammillary nucleus links fasting-induced changes in leptin levels and coordinated luteinizing hormone secretion. J. Neurosci. 29, 5240-5250.

Donato, J. J., Cravo, R. M., Frazão, R., and Elias, C. F. (2011a). Hypothalamic sites of leptin action linking metabolism and reproduction. Neuroendocrinology 93, 9-18.

Donato, J. Jr., Cravo, R. M., Frazão, R. Gautron, L., Scott, M. M., Lachey, J., Castro, I. A., Margatho, L. O., Lee, S., Lee, C., Richardson, J. A., Friedman, J., Chua, S., Coppari, R., Zigman, J. M., Elmquist, J. K., and Elias, C. F. (2011b). Leptin's effect on puberty in mice is relayed by the ventral premammillary nucleus and does not require signaling in Kiss 1 neurons. J. Clin. Invest. 121, 355-368.

Douglass, J., Mckinzie, A. A., and Couceyro, P. (1995). PCR differential display identifies a rat brain mRNA that is transcriptionally regulated by cocaine and amphetamine. J. Neurosci. 15, 2471-2481.

Drewett, R. F. (1973). Oestrous and dioestrous components of the ovarian inhibition on hunger in the rat. Anim. Behav. 21, 772-780.

Duan, J., Choi, Y.-H., Hartzell, D., DellaFera, M. A., Hamrick, M., and Baile, C.A. (2007). Effects of subcutaneous leptin injections on hypothalamic gene profiles in lean and ob/ob mice. Obesity 15, 2624-2633.

Dubois-Dauphin, M., Theler, J. M. Zaganidis, N., Dominik, W., Tribollet, E., Pévet, P., Charpak, G., and Dreifuss, J. J. (1991). Expression of vasopressin receptors in hamster hypothalamus is sexually dimorphic and dependent upon photoperiod. Proc. Natl. Acad. Sci. U.S.A. 88 11163-11167.

Elmquist, J. K., Bjorbaek, C., Ahima, R. S., Flier, J. S., and Saper, C. B. (1998). Distributions of leptin receptor mRNA isoforms in the rat brain. J. Comp. Neurol. 395, 535-547.

Emilsson, V., Arch, J. R. S., De Groot, R. P., Lister, C. A., and Cawthorne, M. A. (1999). Leptin treatment increases suppressors of cytokine signaling in central and periphera tissues. FEBS Lett. 455, 170-174.

Farooqi, I. S., Jebb, S. A., Langmack, G. Lawrence, E., Cheetham, C. H., Prentice, A. M., Hughes, I. A., Mccamish, M. A., and O'rahilly, S. (1999). Effects of recombinant leptin therapy in a child with congenital leptin deficiency. N. Engl. J. Med. 341, 879-884.

Flegal, K. M., Ogden, C. L., Yanovski, J. A., Freedman, D. S., Shepherd, J. A., Graubard, B. I., and Borrud, L. G. (2010). High adiposity and high body mass index-for-age in US children and adolescents overall and by race-ethnic group. Am. J. Clin. Nutr. 91, 1020-1026.

Foster, D. L., and Olster, D. H. (1985). Effect of restricted nutrition on puberty in the lamb: patterns of tonic luteinizing hormone (LH) secretion and competency of the LH surge system. Endocrinology 116, 375-381.

Frederich, R. C., Hamann, A., Anderson, S., Lollmann, B., Lowell, B. B., and Flier, J. S. (1995a). Leptin levels reflect body lipid content in mice: evidence for diet-induced resistance to leptin action. Nat. Med. 1, 1311-1314.

Frederich, R. C., Lollmann, B., Hamann, A., Napolitano-Rosen, A., Kahn, B. B., Lowell, B. B., and Flier, J. S. (1995b). Expression of ob mRNA and its encoded protein in rodents. Impact of nutrition and obesity. $J$. Clin. Invest. 96, 1658-1663.

Friedman, J. M., and Halaas, J. L. (1998). Leptin and the regulation of body weight in mammals. Nature 395, 763-770.

Frisch, R. E. (1985). Fatness, menarche, and female fertility. Perspect. Biol. Med. 28, 611-633.

Frisch, R. E., and McArthur, J. W. (1974). Menstrual cycles: fatness as a determinant of minimum weight for height necessary for their maintenance or onset. Science 185, 949-951.

Gargiulo, P. A., and Donoso, A. O. (1995). Interaction between glutamate and luteinizing hormonereleasing hormone (LHRH) in lordosis behavior and luteinizing hormone release (LH): further studies on NMDA receptor mediation. Physiol. Behav. 58, 169-173.

Gautron, L., and Elmquist, J. K. (2011). Sixteen years and counting: an update on leptin in energy balance. J. Clin. Invest. 121, 2087-2093.

Geary, N., Asarian, L., Korach, K. S., Pfaff, D. W., and Ogawa, S. (2001). Deficits in E2-dependent control of feeding, weight gain, and cholecystokinin satiation in ERalpha null mice. Endocrinology 142 , 4751-4757.

Gonzalez, L. C., Pinilla, L., TenaSempere, M., and Aguilar, E. (1999). Leptin(116-130) stimulates prolactin and luteinizing hormone secretion in fasted adult male rats. Neuroendocrinology 70, 213-220.

Goodman, R. L., Jansen, H. T., Billings, H. J., Coolen, L. M., and Lehman, M. N. (2010). Neural systems mediating seasonal breeding in the ewe. J. Neuroendocrinol. 22, 674-681. 
Gottsch, M. L., Cunningham, M. J., Smith, J. T., Popa, S. M., Acohido, B. V., Crowley, W. F., Seminara, S., Clifton, D. K., and Steiner, R. A. (2004). A role for kisspeptins in the regulation of gonadotropin secretion in the mouse. Endocrinology 145, 4073-4077.

Gyurko, R., Leupen, S., and Huang, P. L. (2002). Deletion of exon 6 of the neuronal nitric oxide synthase gene in mice results in hypogonadism and infertility. Endocrinology 143, 2767-2774.

Hahn, J. D., and Coen, C. W. (2006). Comparative study of the sources of neuronal projections to the site of gonadotrophin-releasing hormone perikarya and to the anteroventral periventricular nucleus in female rats. J. Comp. Neurol. 494, 190-214.

Halaas, J. L., Gajiwala, K. S., Maffei, M., Cohen, S. L., Chait, B. T., Rabinowitz, D., Lallone, R. L., Burley, S. K., and Friedman, J. M. (1995). Weightreducing effects of the plasma protein encoded by the obese gene. Science 269, 543-546.

Halpern, M., and Martinez-Marcos, A. (2003). Structure and function of the vomeronasal system: an update. Prog. Neurobiol. 70, 245-318.

Hazlerigg, D. G., and Wagner, G. C. (2006). Seasonal photoperiodism in vertebrates: from coincidence to amplitude. Trends Endocrinol. Metab. 17, 83-91.

Herbison, A. E. (2008). Estrogen positive feedback to gonadotropinreleasing hormone ( $\mathrm{GnRH})$ neurons in the rodent: the case for the rostral periventricular area of the third ventricle (RP3V). Brain Res. Rev. 57, 277-287.

Hill, J. W., Elmquist, J. K., and Elias, C. F. (2008). Hypothalamic pathways linking energy balance and reproduction. Am. J. Physiol. Endocrinol. Metab. 294, E827-E832.

Intlekofer, K. A., and Petersen, S. L. (2011). Distribution of mRNAs encoding classical progestin receptor, progesterone membrane components 1 and 2, serpine mRNA binding protein 1 , and progestin and ADIPOQ receptor family members 7 and 8 in rat forebrain. Neuroscience 172, 55-65.

Johnson, L. M., and Sidman, R. L. (1979). A reproductive endocrine profile in the diabetes $(\mathrm{db})$ mutant mouse. Biol. Reprod. 20, 552-559.

Kamel, F., Wright, W. W., Mock, E. J., and Frankel, A. I. (1977). The influence of mating and related stimuli on plasma levels of luteinizing hormone, follicle stimulating hormone, prolactin, and testosterone in the male rat. Endocrinology 101, 421-429.

Kang, S. W., Leclerc, B., Kosonsiriluk, S., Mauro, L. J., Iwasawa, A., and El Halawani, M. E. (2010). Melanopsin expression in dopamine-melatonin neurons of the premammillary nucleus of the hypothalamus and seasonal reproduction in birds. $\mathrm{Neu}$ roscience 170, 200-213.

Kang, S. W., Thayananuphat, A., Bakken, T., and El Halawani, M. E. (2007). Dopamine-melatonin neurons in the avian hypothalamus controlling seasonal reproduction. $\mathrm{Neu}$ roscience 150, 223-233.

Kennedy, G. C. (1953). The role of depot fat in the hypothalamic control of food intake in the rat. Proc. R. Soc. Lond. B Biol. Sci. 140, 578-596.

Kennedy, G. C. (1969). The relation between the central control of appetite, growth and sexual maturation. Guys Hosp. Rep. 118, 315-327.

Kennedy, G. C., and Mitra, J. (1963). Body weight and food intake as initiating factors for puberty in the rat. J. Physiol. (Lond.) 166, 408-418.

Kishi, T., Aschkenasi, C. J., Choi, B. J., Lopez, M. E., Lee, C. E., Liu, H., Hollenberg, A. N., Friedman, J. M., and Elmquist, J. K. (2005). Neuropeptide Y Y1 receptor mRNA in rodent brain: distribution and colocalization with melanocortin-4 receptor. J. Comp. Neurol. 482, 217-243.

Kishi, T., Aschkenasi, C. J., Lee, C. E., Mountjoy, K. G., Saper, C. B., and Elmquist, J. K. (2003). Expression of melanocortin 4 receptor mRNA in the central nervous system of the rat. J. Comp. Neurol. 457, 213-235.

Kollack-Walker, S., and Newman, S. W. (1995). Mating and agonistic behavior produce different patterns of Fos immunolabeling in the male Syrian hamster brain. Neuroscience 66, 721-736.

Koylu, E. O., Couceyro, P. R., Lambert, P. D., Ling, N. C., Desouza, E. B., and Kuhar, M. J. (1997). Immunohistochemical localization of novel CART peptides in rat hypothalamus, pituitary and adrenal gland. $J$. Neuroendocrinol. 9, 823-833.

Larsen, P. J. (1992). Distribution of substance P-immunoreactive elements in the preoptic area and the hypothalamus of the rat. J. Comp. Neurol. 316, 287-313.

Lebrethon, M. C., Aganina, A., Fournier, M., Gerard, A., Parent, A. S., and Bourguignon, J. P. (2007). Effects of in vivo and in vitro administration of ghrelin, leptin and neuropeptide mediators on pulsatile gonadotrophin-releasing hormone secretion from male rat hypothalamus before and after puberty. J. Neuroendocrinol. 19, 181-188.

Lebrethon, M. C., Vandersmissen, E., Gerard, A., Parent, A. S., and Bourguignon, J. P. (2000). Cocaine and amphetamine-regulatedtranscript peptide mediation of leptin stimulatory effect on the rat gonadotropin-releasing hormone pulse generator in vitro. $J$. Neuroendocrinol. 12, 383-385.

Leclerc, B., Kang, S. W., Mauro, L. J., Kosonsiriluk, S., Chaiseha, Y., and El Halawani, M. E. (2010). Photoperiodic modulation of clock gene expression in the avian premammillary nucleus. J. Neuroendocrinol. 22 119-128.

Leshan, R. L., Louis, G. W., Jo, Y.H., Rhodes, C. J., Munzberg, H., and Myers, M. G. Jr. (2009). Direct innervation of GnRH neurons by metabolic- and sexual odorantsensing leptin receptor neurons in the hypothalamic ventral premammillary nucleus. J. Neurosci. 29, 3138-3147.

Liu, H., Kishi, T., Roseberry, A. G. Cai, X., Lee, C. E., Montez, J. M., Friedman, J. M., and Elmquist, J. K. (2003). Transgenic mice expressing green fluorescent protein under the control of the melanocortin-4 receptor promoter. J. Neurosci. 23, 7143-7154.

Louis, G. W., Greenwald-Yarnell, M. Phillips, R., Coolen, L. M., Lehman, M. N., and Myers, M. G. Jr. (2011). Molecular mapping of the neural pathways linking leptin to the neuroendocrine reproductive axis. Endocrinology 152, 2302-2310.

Maffei, M., Halaas, J., Ravussin, E., Pratley, R. E., Lee, G. H., Zhang, Y., Fei, H., Kim, S., Lallone, R., Ranganathan, S., Kern, P. A., and Friedman, J. M. (1995). Leptin levels in human and rodent: measurement of plasma leptin and ob RNA in obese and weight-reduced subjects. Nat. Med. 1, 1155-1161.

Mahesh, V. B., and Brann, D. W. (2005). Regulatory role of excitatory amino acids in reproduction. Endocrine 28, 271-280.

Malpaux, B., Daveau, A., MauriceMandon, F., Duarte, G., and Chemineau, P. (1998). Evidence that melatonin acts in the premammillary hypothalamic area to control reproduction in the ewe: presence of binding sites and stimulation of luteinizing hormone secretion by in situ microimplant delivery. Endocrinology 139, 1508-1516.

Mani, S. K., Allen, J. M., Rettori, V., Mccann, S. M., O'malley, B. W., and Clark, J. H. (1994). Nitric oxide mediates sexual behavior in female rats. Proc. Natl. Acad. Sci. U.S.A. 91, 6468-6472.

Marcus, J. N., Aschkenasi, C. J., Lee, C. E., Chemelli, R. M., Saper, C. B., Yanagisawa, M., and Elmquist, J. K. (2001). Differential expression of orexin receptors 1 and 2 in the rat brain. J. Comp. Neurol. 435, 6-25.

Maruniak, J. A., and Bronson, F. H. (1976). Gonadotropic responses of male mice to female urine. Endocrinology 99, 963-969.

McCann, S. M., Mastronardi, C., Walczewska, A., Karanth, S., Rettori, V., and Yu, W. H. (1999). The role of nitric oxide in reproduction. Braz. J. Med. Biol. Res. 32, 1367-1379.

Merchenthaler, I., Lane, M. V., Numan, S., and Dellovade, T. L. (2004) Distribution of estrogen receptor $\alpha$ and $\beta$ in the mouse central nervous system: in vivo autoradiographic and immunocytochemical analyses. J. Comp. Neurol. 473, 270-291.

Montague, C. T., Farooqi, I. S., Whitehead, J. P., Soos, M. A., Rau, H., Wareham, N. J., Sewter, C. P., Digby, J. E., Mohammed, S. N., Hurst, J. A., Cheetham, C. H., Earley, A. R., Barnett, A. H., Prins, J. B., and O'rahilly, S. (1997). Congenital leptin deficiency is associated with severe earlyonset obesity in humans. Nature 387, 903-908.

Moretto, M., Lopez, F., and Negro-Vilar, A. (1993). Nitric oxide regulates luteinizing hormone-releasing hormone secretion. Endocrinology 133, 2399-2402.

Mounzih, K., Lu, R., and Chehab, F. F. (1997). Leptin treatment rescues the sterility of genetically obese ob/ob males. Endocrinology 138, 1190-1193.

Nagatani, S., Guthikonda, P., Thompson, R. C., Tsukamura, H., Maeda, K. I., and Foster, D. L. (1998). Evidence for GnRH regulation by leptin: leptin administration prevents reduced pulsatile LH secretion during fasting. Neuroendocrinology 67, 370-376.

Nelson, R. J., Demas, G. E., Huang, P. L., Fishman, M. C., Dawson, V. L., Dawson, T. M., and Snyder, S. H. (1995). Behavioural abnormalities in male mice lacking neuronal nitric oxide synthase. Nature 378, 383-386. 
Ojeda, S. R., Lomniczi, A., Mastronardi, C., Heger, S., Roth, C., Parent, A. S., Matagne, V., and Mungenast, A. E. (2006). Minireview: the neuroendocrine regulation of puberty: is the time ripe for a systems biology approach? Endocrinology 147, 1166-1174.

Parent, A. S., Lebrethon, M. C., Gerard, A., Vandersmissen, E., and Bourguignon, J. P. (2000). Leptin effects on pulsatile gonadotropin releasing hormone secretion from the adult rat hypothalamus and interaction with cocaine and amphetamine regulated transcript peptide and neuropeptide Y. Regul. Pept. 92, 17-24.

Parkash, J., D'anglemont De Tassigny, X., Bellefontaine, N., Campagne, C., Mazure, D., Buee-Scherrer, V., and Prevot, V. (2010). Phosphorylation of N-methyl-D-aspartic acid receptor-associated neuronal nitric oxide synthase depends on estrogens and modulates hypothalamic nitric oxide production during the ovarian cycle. Endocrinology 151, 2723-2735.

Pelleymounter, M. A., Cullen, M. J., Baker, M. B., Hecht, R., Winters, D., Boone, T., and Collins, F. (1995). Effects of the obese gene product on body weight regulation in ob/ob mice. Science 269, 540-543.

Petersen, S. L., Gardner, E., Adelman, J., and Mccrone, S. (1996). Examination of steroid-induced changes in LHRH gene transcription using 33P-and 35S-labeled probes specific for intron 2. Endocrinology 137, 234-239.

Pfaus, J. G., and Heeb, M. M. (1997). Implications of immediateearly gene induction in the brain following sexual stimulation of female and male rodents. Brain Res. Bull. 44, 397-407.

Rettori, V., Belova, N., Dees, W. L., Nyberg, C. L., Gimeno, M., and Mccann, S. M. (1993). Role of nitric oxide in the control of luteinizing hormone-releasing hormone release in vivo and in vitro. Proc. Natl. Acad. Sci. U.S.A. 90, 10130-10134.

Reynoso, R., Cardoso, N., Szwarcfarb, B., Carbone, S., Ponzo, O., Moguilevsky, J. A., and Scacchi, P. (2007). Nitric oxide synthase inhibition prevents leptin induced $\mathrm{Gn}-\mathrm{RH}$ release in prepubertal and peripubertal female rats. Exp. Clin. Endocrinol. Diabetes 115, 423-427.

Ribeiro, S. M., Dos Santos, Z. A., Da Silva, R. J., Louzada, E., Donato, J. Jr., and Tirapegui, J. (2007). Leptin: aspects on energetic balance, physical exercise and athletic amenorhea.
Arq. Bras. Endocrinol. Metabol. 51, 11-24.

Romero, P. R., Beltramino, C. A., and Carrer, H. F. (1990). Participation of the olfactory system in the control of approach behavior of the female rat to the male. Physiol. Behav. 47, 685-690.

Rondini, T. A., Baddini, S. P., Sousa, L. F., Bittencourt, J. C., and Elias, C. F. (2004). Hypothalamic cocaine- and amphetamineregulated transcript neurons project to areas expressing gonadotropin releasing hormone immunoreactivity and to the anteroventral periventricular nucleus in male and female rats. Neuroscience 125, 735-748.

Rosenbaum, M., and Leibel, R. L. (1998). Leptin: a molecule integrating somatic energy stores, energy expenditure and fertility. Trends Endocrinol. Metab. 9, 117-124.

Schwartz, M. W. (2006). Central nervous system regulation of food intake. Obesity (Silver Spring) 14(Suppl. 1), 1S-8S.

Schwartz, M. W., Seeley, R. J., Campfield, L. A., Burn, P., and Baskin, D. G. (1996). Identification of targets of leptin action in rat hypothalamus. $J$. Clin. Invest. 98, 1101-1106.

Scott, M. M., Lachey, J. L., Sternson, S. M., Lee, C. E., Elias, C. F., Friedman, J. M., and Elmquist, J. K. (2009). Leptin targets in the mouse brain. J. Comp. Neurol. 514, 518-532.

Shimada, S., Inagaki, S., Kubota, Y., Kito, S., Shiotani, Y., and Tohyama, M. (1987). Coexistence of substance Pand enkephalin-like peptides in single neurons of the rat hypothalamus. Brain Res. 425, 256-262.

Simerly, R. B., Chang, C., Muramatsu, M., and Swanson, L. W. (1990). Distribution of androgen and estrogen receptor mRNA-containing cells in the rat brain: an in situ hybridization study. J. Comp. Neurol. 294, 76-95.

Simerly, R. B., and Swanson, L. W. (1988). Projections of the medial preoptic nucleus: a Phaseolus vulgaris leucoagglutinin anterograde tract-tracing study in the rat. J. Comp. Neurol. 270, 209-242.

Sliwowska, J. H., Billings, H. J., Goodman, R. L., Coolen, L. M., and Lehman, M. N. (2004). The premammillary hypothalamic area of the ewe: anatomical characterization of a melatonin target area mediating seasonal reproduction. Biol. Reprod. 70, 1768-1775.

Smith, J. T., Popa, S. M., Clifton, D. K., Hoffman, G. E., and Steiner, R. A.
(2006). Kiss1 neurons in the forebrain as central processors for generating the preovulatory luteinizing hormone surge. J. Neurosci. 26, 6687-6694.

Strobel, A., Issad, T., Camoin, L., Ozata, M., and Strosberg, A. D. (1998). A leptin missense mutation associated with hypogonadism and morbid obesity. Nat. Genet. 18, 213-215.

Sukhov, R. R., Walker, L. C., Rance, N. E., Price, D. L., and Young, W. S. III. (1995). Opioid precursor gene expression in the human hypothalamus. J. Comp. Neurol. 353, 604-622.

Terasawa, E., and Fernandez, D. L. (2001). Neurobiological mechanisms of the onset of puberty in primates. Endocr. Rev. 22, 111-151.

Thayananuphat, A., Kang, S. W. Bakken, T., Millam, J. R., and El Halawani, M. E. (2007). Rhythmic dependent light induction of gonadotrophin-releasing hormoneI expression and activation of dopaminergic neurones within the premammillary nucleus of the Turkey hypothalamus. J. Neuroendocrinol. 19, 399-406.

Van Den Berg, M., Ter Horst, G., and Koolhaas, J. (1983). The nucleus premammillaris ventralis (PMV) and aggressive behavior in the rat. Aggress. Behav. 9, 41-47.

Vincent, S. R., and Kimura, H. (1992). Histochemical mapping of nitric oxide synthase in the rat brain. $\mathrm{Neu}$ roscience 46, 755-784.

Vong, L., Ye, C., Yang, Z., Choi, B., Chua, S., and Lowell, B. B. (2011). Leptin action on GABAergic neurons prevents obesity and reduces inhibitory tone to POMC neurons. Neuron 71, 142-154.

Wamsley, J. K., Young, W. S. III, and Kuhar, M. J. (1980). Immunohistochemical localization of enkephalin in rat forebrain. Brain Res. 190, 153-174.

Warren, M. P., Voussoughian, F., Geer, E. B., Hyle, E. P., Adberg, C. L., and Ramos, R. H. (1999). Functional hypothalamic amenorrhea: hypoleptinemia and disordered eating. J. Clin. Endocrinol. Metab. 84, 873-877.

Watanobe, H., and Schioth, H. B. (2001). Nitric oxide mediates leptin-induced preovulatory luteinizing hormone and prolactin surges in rats. Brain Res. 923, 193-197.

Watanobe, H., Suda, T., Wikberg, J. E., and Schioth, H. B. (1999). Evidence that physiological levels of circulating leptin exert a stimulatory effect on luteinizing hormone and prolactin surges in rats. Biochem. Biophys. Res. Commun. 263, 162-165.

Welt, C. K., Chan, J. L., Bullen, J., Murphy, R., Smith, P., Depaoli, A. M., Karalis, A., and Mantzoros, C. S. (2004). Recombinant human leptin in women with hypothalamic amenorrhea. N. Engl. J. Med. 351, 987-997.

Wiegand, S. J., and Terasawa, E. (1982). Discrete lesions reveal functional heterogeneity of suprachiasmatic structures in regulation of gonadotropin secretion in the female rat. Neuroendocrinology 34, 395-404.

Wikelski, M., Martin, L. B., Scheuerlein, A., Robinson, M. T., Robinson, N. D., Helm, B., Hau, M., and Gwinner, E. (2008). Avian circannual clocks: adaptive significance and possible involvement of energy turnover in their proximate control. Philos. Trans. R. Soc. Lond. B Biol. Sci. 363, 411-423.

Williams, K. W., Sohn, J.-W., Donato, J., Lee, C. E., Zhao, J. J., Elmquist, J. K., and Elias, C. F. (2011). The acute effects of leptin require PI3K signaling in the hypothalamic ventral premammillary nucleus. J. Neurosci. 31, 13147-13156.

Wu, M. V., Manoli, D. S., Fraser, E. J., Coats, J. K., Tollkuhn, J., Honda, S.-I., Harada, N., and Shah, N. M. (2009). Estrogen masculinizes neural pathways and sex-specific behaviors. Cell 139, 61-72.

Yokosuka, M., and Hayashi, S. (1996). Colocalization of neuronal nitric oxide synthase and androgen receptor immunoreactivity in the premammillary nucleus in rats. Neurosci. Res. 26, 309-314.

Yokosuka, M., Matsuoka, M., OhtaniKaneko, R., Iigo, M., Hara, M. Hirata, K., and Ichikawa, M. (1999). Female-soiled bedding induced fos immunoreactivity in the ventral part of the premammillary nucleus (PMv) of the male mouse. Physiol. Behav. 68, 257-261.

Yoon, H., Enquist, L. W., and Dulac, C. (2005). Olfactory inputs to hypothalamic neurons controlling reproduction and fertility. Cell 123, 669-682.

Yu, W. H., Walczewska, A., Karanth, S., and Mccann, S. M. (1997). Nitric oxide mediates leptin-induced luteinizing hormone-releasing hormone (LHRH) and LHRH and leptin-induced $\mathrm{LH}$ release from the pituitary gland. Endocrinology 138, 5055-5058. 
Zamorano, P. L., Mahesh, V. B., De Sevilla, L., and Brann, D. W. (1998). Excitatory amino acid receptors and puberty. Steroids 63, 268-270.

Zamorano, P. L., Mahesh, V. B., De Sevilla, L. M., Chorich, L. P., Bhat, G. K., and Brann, D. W. (1997). Expression and localization of the leptin receptor in endocrine and neuroendocrine tissues of the rat. Neuroendocrinology 65, 223-228.

Zhang, Y., Proenca, R., Maffei, M. Barone, M., Leopold, L., and
Friedman, J. M. (1994). Positional cloning of the mouse obese gene and its human homologue. Nature 372, 425-432.

Ziegler, D. R., Cullinan, W. E., and Herman, J. P. (2002). Distribution of vesicular glutamate transporter mRNA in rat hypothalamus. J. Comp. Neurol. 448, 217-229.

Zigman, J. M., Jones, J. E., Lee, C. E., Saper, C. B., and Elmquist, J. K. (2006). Expression of ghrelin receptor mRNA in the rat and the mouse brain. J. Comp. Neurol. 494, 528-548.
Conflict of Interest Statement: The authors declare that the research was conducted in the absence of any commercial or financial relationships that could be construed as a potential conflict of interest.

Received: 04 August 2011; paper pending published: 22 August 2011; accepted: 04 October 2011; published online: 25 October 2011.

Citation: Donato Jr. and Elias CF (2011) The ventral premammillary nucleus links metabolic cues and reproduction. Front. Endocrin. 2:57. doi: 10.3389/fendo.2011.00057

This article was submitted to Frontiers in Systems and Translational Endocrinology, a specialty of Frontiers in Endocrinology.

Copyright $(92011$ Donato and Elias. This is an open-access article subject to a nonexclusive license between the authors and Frontiers Media SA, which permits use, distribution and reproduction in other forums, provided the original authors and source are credited and other Frontiers conditions are complied with. 